\title{
A Case of Nasal Angiomyolipoma in Young Man
}

\author{
Min Chul Ko ${ }^{1}$, Sung Jae $\mathrm{Heo}^{2}$, and Jung Soo Kim ${ }^{1}$ \\ Department of Otorhinolaryngology-Head and Neck Surgery, School of Medicine, Kyungpook National University, ${ }^{1}$ Kyungpook National \\ University Hospital, Daegu; and ${ }^{2}$ Kyungpook National University Chilgok Hospital, Daegu, Korea
}

\section{젊은 남자에게 발생한 비강내 혈관근육지방종 1 예}

고민철 ${ }^{1}$ 허성재 ${ }^{2} \cdot$ 김정수 ${ }^{1}$

경북대학교 의과대학 이비인후과 경북대학교병원, ${ }^{1}$ 칠곡경북대학교병원 ${ }^{2}$

\author{
Received January 5, 2019 \\ Revised March 14, 2019 \\ Accepted March 22, 2019 \\ Address for correspondence \\ Jung Soo Kim, MD, PhD \\ Department of Otorhinolaryngology- \\ Head and Neck Surgery, \\ School of Medicine, \\ Kyungpook National \\ University Hospital, \\ 130 Dongdeok-ro, Jung-gu, \\ Daegu 41944, Korea \\ Tel +82-53-200-5777 \\ Fax +82-53-423-4524 \\ E-mail sookim@knu.ac.kr
}

\begin{abstract}
Angiomyolipoma is a benign tumor that is composed of adipose tissue, blood vessels and smooth muscle. The kidney is the most common site for this tumor. Although extrarenal angiomyolipoma is rarely found in areas other than the kidney, it has been observed in other organs such as liver, heart, mediastinum, spermatic cord, vaginal wall, oral cavity, and so on. Angiomyolipoma in the nasal cavity especially, has been very rarely reported in literature. Furthermore, nasal angiomyolipoma is mostly found in middle aged or old men. In this case, angiomyolipoma was found in a 29 -year-old male patient who was the youngest of the reported cases. He complained of nasal obstruction and physical examination revealed a $1.5 \mathrm{~cm}$ sized mass in the left posterior part of the nasal septum. The mass was composed of an intimate mixture of mature fat, smooth muscle cells, and thick walled varying sized blood vessels histopathologically coinciding with angiomyolipoma. It was removed via endoscopic surgery without complications.

Korean J Otorhinolaryngol-Head Neck Surg 2020;63(2):76-80
\end{abstract}

\section{서 론}

혈관근육지방종은 성숙된 지방조직, 평활근 그리고 여러 크기의 혈관으로 구성된 양성종양으로 신장에서 가장 흔히 발생하고 간에서 두 번째로 호발하나, 신장과 간 이외의 조직 에서는 거의 발생하지 않는다. ${ }^{1)}$ 종격동, 심장, 정삭(spermatic cord), 질벽, 나팔관, 피부, 구강 그리고 인두 등에서 혈관근육 지방종이 드물게 보고되는데, 특히 비강에서의 발생은 매우 드물며 1988년에 Dawlatly 등리 이 처음 보고한 이후, 문헌상 지금까지 총 15 예가 보고되었으며 그 중 국내 보고가 3 예 ${ }^{3-5)}$ 이다. 비강 내 혈관근육지방종은 신장과 간에서 발생한 혈관 근육지방종과 다른 병리적, 임상적 특징을 가지며, 40대 이상 의 중년 남성에서 대부분 발생하였다. ${ }^{4)}$ 지금까지 비강에서 발

This is an Open Access article distributed under the terms of the Creative Commons Attribution Non-Commercial License (https://creativecommons.org/licenses/by-nc/4.0) which permits unrestricted non-commercial use, distribution, and reproduction in any medium, provided the original work is properly cited.
생한 혈관근육지방종의 문헌 고찰과 함께 보고된 환자 중 가 장 젊은 나이에 발생한 혈관근육지방종 증례를 보고하고자 한다.

\section{증 례}

29세 남자 환자가 어렸을 때부터 계절에 따라 악화되는 양 측 비폐색을 주소로 내원하였다. 과거력 및 가족력에서 특이 사항은 없었다. 비내시경 검사에서 좌측 후방에 약 $1.5 \mathrm{~cm}$ 가 량의 연한 분홍색의 둥근 종물이 관찰되었으며(Fig. 1A), 종 물의 표면 점막에는 혈관이 잘 발달되어 있었다(Fig. 1B). 알 레르기 피부반응 검사에서 집 먼지 진드기에 강한 양성소견 을 보였고, 혈액 검사에서 특이소견은 없었다. 부비동 전산 단층촬영상 좌측 비강바닥 후방부와 후비공 사이에 $1.5 \mathrm{~cm}$ 크기의 연조직음영소견이 보였으며 주위 골조직의 파괴나 침 범소견 및 주위 림프절 비대소견은 관찰되지 않았다(Fig. 2). 

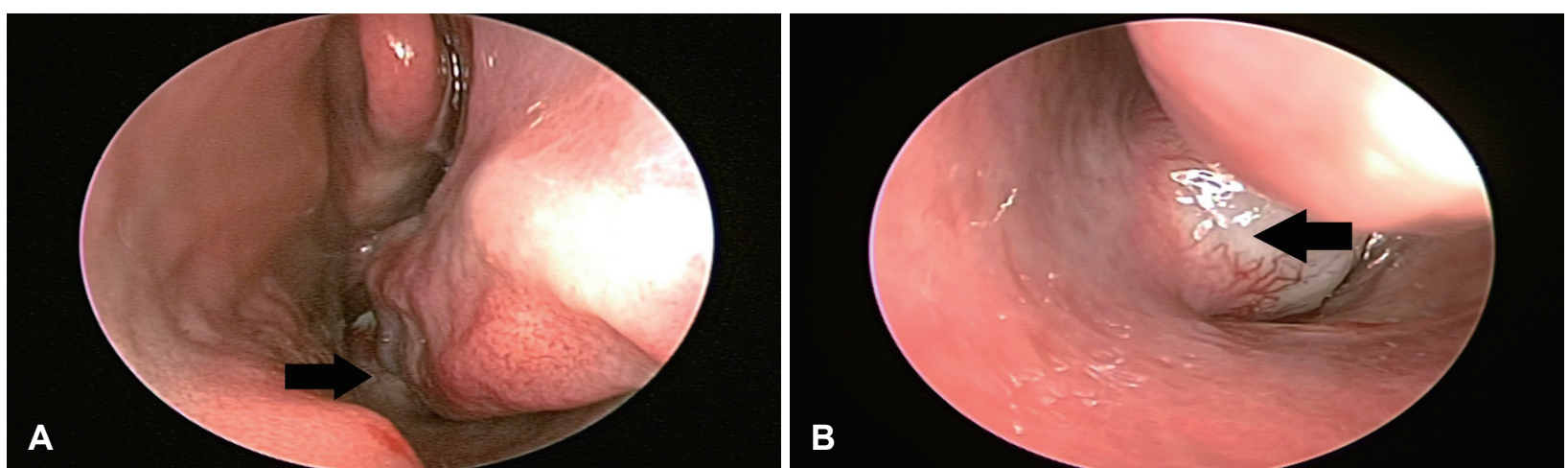

Fig. 1. Nasoendoscopy findings. Mass (arrow) is located at left posterior nasal septum (A). A bulging mass (arrow) is hyper-vascularized (B).

종물의 진단과 치료를 위해 국소마취하에 비내시경적 접 근을 통한 종물의 절제를 계획하였고, 종물은 주변 조직과 유착 없이 쉽게 분리되어 완전히 제거되었다. 종물 제거 후 절제 부위는 전기소작과 cutanplast $^{\circledR}$ (Cutanplast Standard, Mascia brunelli, Milano, Italy) 패킹을 하여 지혈하였고, 술 후 비출혈은 없었다. 제거된 종물은 $15 \times 12 \times 10 \mathrm{~mm}$ 의 회백 색의 둥근 모양이었고 단단하였으며 종물을 잘랐을 때 황갈 색이 섞인 회색의 단면이 확인되었다(Fig. 3). 현미경소견에서 종물은 평활근조직과 여러 크기의 혈관 그리고 전반적으로 산재된 성숙한 지방조직으로 구성되어 있었으며 trichrome 특수염색, $\mathrm{HMB}-45$, desmin, 그리고 $\mathrm{CD} 34$ 의 면역화학염색 을 시행하였고, trichrome 양성, HMB-45 음성, desmin 양 성, 그리고 $\mathrm{CD} 34$ 양성이었다. 혈관벽과 혈관 사이의 평활근 세포에서 desmin 양성소견이 관찰되었으며, 혈관의 내피세포 를 염색하는 CD34 면역화학 검사에서 다양한 크기의 혈관 이 염색되었고, 이는 혈관근육지방종의 조직학적 소견에 해 당하였다(Fig. 4).

환자는 수술 후 출혈 및 감염 등의 합병증 없이 회복되었 고 수술 전 호소하였던 비폐색 증상은 호전되었으며, 13개월 동안 재발소견 없이 추적 관찰 중이다.

\section{고 찰}

혈관근육지방종의 유병률은 $0.3 \%$ 로 신장에서 가장 빈번 하게 발생하고 간에서 두 번째로 흔히 발생한다.) 신장과 간 에서 발생한 혈관근육지방종은 결절경화증을 동반하는 경 우와 산발적으로 발생하는 경우가 있고 신장에 생긴 혈관근 육지방종 환자의 $20 \%$ 에서 결절성경화증이 동반되어 발생하 며 결절성경화증 환자의 $80 \%$ 에서 혈관근육지방종이 나타나 는 것으로 알려져 있다.) 그리고 $\mathrm{HMB}-45$ 면역화학염색 시 보통 양성이며 이는 진단에 중요한 소견이다. ${ }^{7)}$

신장과 간에 생긴 혈관근육지방종이 $4 \mathrm{~cm}$ 에서 $45 \mathrm{~cm}$ 까지
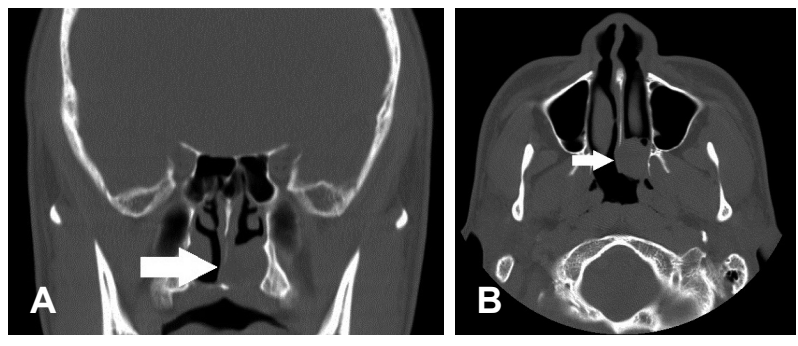

Fig. 2. CT scans showing a soft tissue mass density arising from left posterior nasal septum without signs of bone destruction. Posterior septum (arrow) was deviated toward the right nasal cavity in the axial view (A) and coronal view (B).

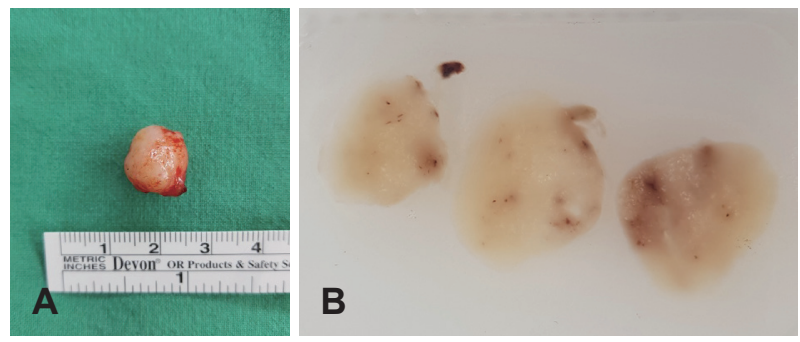

Fig. 3. Gross findings. A mass is about $15 \times 12 \times 10 \mathrm{~mm}$ sized, whitish round mass (A). Grey-brown colored cross section of the mass (B).

의 큰 크기를 가지는 것에 비해 신장과 간 외의 혈관근육지 방종은 종물의 크기는 $1.5 \sim 4 \mathrm{~cm}$ 로 작다. ${ }^{6}$ 신장과 간에 생긴 혈관근육지방종은 중년의 여성에서 호발하나, 신장과 간 외 의 혈관근육지방종은 중년의 남성에서 호발한다. 그리고 신 장과 간에 생긴 혈관근육지방종과는 다르게 유상피세포, HMB-45 특수염색에서 음성이며, 결정경화증이 동반되지 않는다는 차이점이 있다. ${ }^{1)}$ 이러한 차이점이 있어 Watanabe와 Suzuki')는 신장과 간 외에서 발생한 혈관근육지방종을 '점 막피부 혈관근육지방종라는 용어를 써서 표현하였다.

신장과 간의 혈관근육지방종은 종종 침습적이며 국소적 림 프절 침범을 하는 경우가 있으나 신장과 간 외에서 발생한 혈 관근육지방종은 비교적 경계가 명확하고 수술로 절제하기 어 렵지 않으며 수술 후 재발한 증례가 보고되지 않아 수술적으 

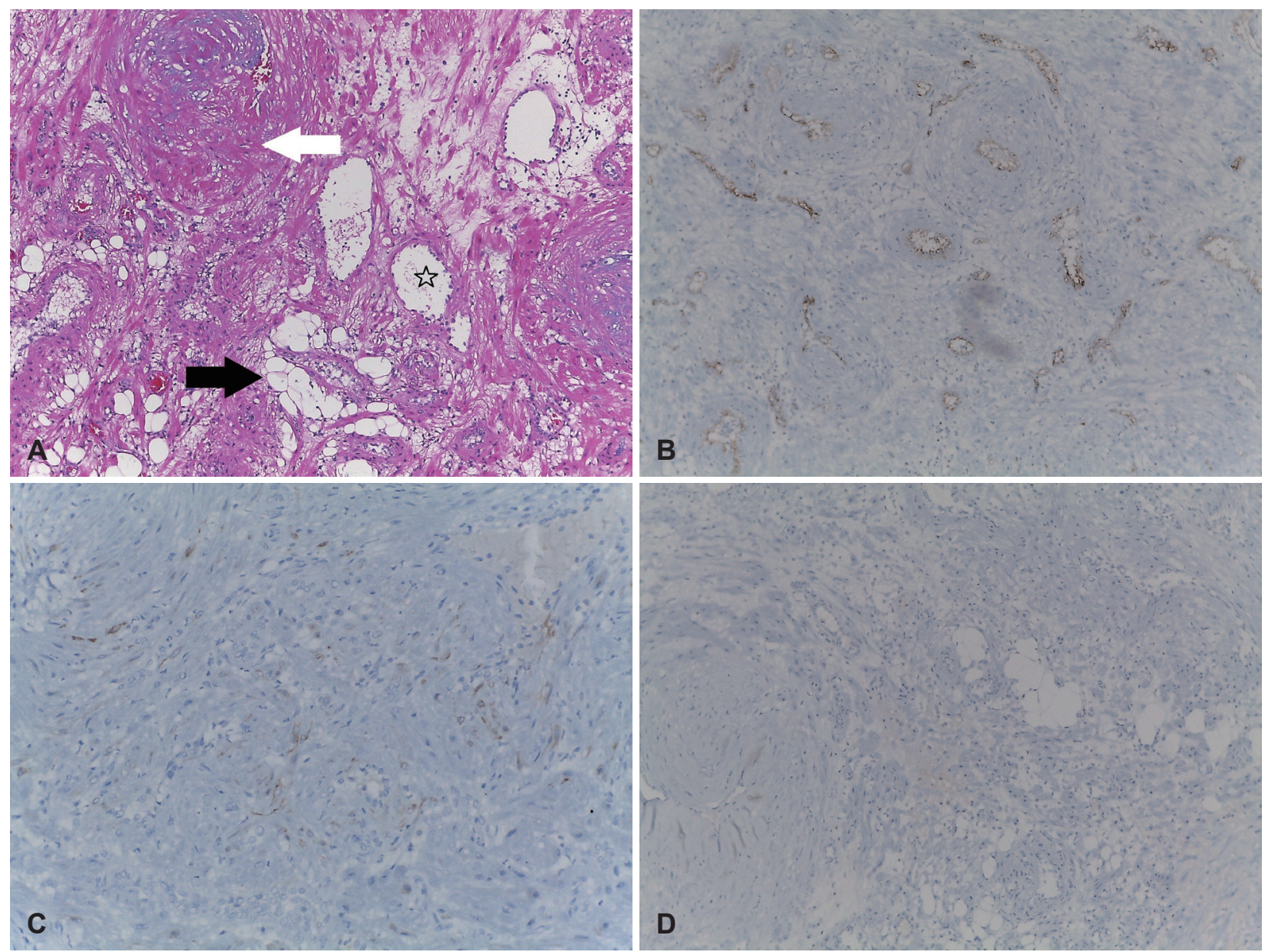

Fig. 4. Histopathologic findings. The mass predominantly consisted of bundles of smooth muscles (white arrow) and mature fat cells (black arrow) (A). Thick-walled blood vessels (star) were also found (A: hematoxylin and eosin staining, $\times 100)$. High microvessel density (B: CD34, $\times 100)$. Focal cytoplasmic positivity in smooth muscle cells for desmin (C: desmin, $\times 200)$. HMB-45 immunochemical staining was negative $(D: H M B 45, \times 100)$.

로 완전한 절제가 치료원칙이다. ${ }^{8)}$ 하지만 출혈이 예상되거나 수술적 접근이 힘든 경우 혈관 색전술이 필요할 수도 있다. ${ }^{4}$

지금까지 보고된 비강에서 발생한 혈관근육지방종의 증례 들과 본례를 요약하여 Table 1에 정리하였다..$^{1-69-15)}$ 이들 환자 중 비교적 젊은 나이인 34세 여자 환자에서 발생한 경우는 비 강에서 발생한 다른 증례와는 다르게 유상피세포가 관찰되 며, HMB-45 특수염색에서 양성소견을 보여, 비강에 발생하 였으나 병리학적으로는 점막피부 혈관근육지방종에 해당하 지 않으며, 신장과 간에서 발생한 혈관근육지방종의 병리소 견에 합당하였다. ${ }^{11)}$ 따라서 34 세 환자를 제외한 기존 증례의 환자 연령은 44세에서 88세이며 평균 나이는 58세로 일반적 으로 중년의 나이에 호발하나 본례의 경우 29 세로 나이가 가장 어렸다.

신장과 간에서 발생한 혈관근육지방종은 병리학적으로 세 포학적 이형성과 산재된 분열상 소견을 보일 수 있으며그드물 게 악성 변화를 일으킬 수 있으나, 비강 내 발생한 혈관근육
지방종은 이형성이나 분열상을 보이지 않으며, 악성 변화 또 한 보고된 바 없다. ${ }^{6}$ 또한 신장과 간에서 발생한 혈관근육지 방종은 진단 시 큰 크기로, 크기 증가에 따라 통증과 심각한 출혈을 일으킬 수 있다. ${ }^{16)}$ 이와는 다르게 비강 내 혈관근육지 방종은 비출혈이 있을 수 있으나 생명을 위협하는 심각한 출 혈은 아니며, 비강의 일부를 막아 발생한 코막힘과 같은 경 한 증상이 대부분이었다. 이와 같이 구분된 임상적, 병리학 적 특성을 고려하였을 때 비강 내 발생한 혈관근육지방종이 신장과 간에서 발생한 혈관근육지방종보다 더 양성 종양의 성향을 보이며, 느리게 진행하기 때문에 질환의 발견 연령이 더 고령일 것으로 추측해 볼 수 있다. 본례의 경우 알레르기 비염 증상으로 내원하여 내시경 검사에서 우연히 종물을 발 견하였으며, 비강 내 혈관근육지방종이 비교적 젊은 나이에 발생할 수 있으나 서서히 자라며 임상증상이 심하지 않아 중 년 이상의 나이에 주로 발견되었을 것으로 생각된다.

신장과 간에서 발생한 혈관근육지방종이 중년의 여성에서 
Nasal Angiomyolipoma I Ko MC, et al.

Table 1. Previously reported cases of nasal angiomyolipoma

\begin{tabular}{|c|c|c|c|c|c|c|c|}
\hline Reference & Sex/Age & Nation & Chief complaint & Location & Medical Hx & Size & Year \\
\hline Dawlatly et al. ${ }^{2)}$ & $52 / \mathrm{M}$ & Saudi Arabia & $\begin{array}{l}\text { Nasal obstruction, } \\
\text { Recurrent epistaxis }\end{array}$ & Rt naso-labial fold & $\mathrm{DM}, \mathrm{HTN}$ & 40 & 1988 \\
\hline Güezmes et al.9) & $66 / F$ & Spain & ND & Rt nasal cavity & DM & 15 & 1990 \\
\hline Gatalica et al..$^{10)}$ & $64 / M$ & US & Nasal obstruction & Rt nasal vestibule & None & 20 & 1994 \\
\hline Watanabe and Suzukil) & $66 / M$ & Japan & Nasal mass & Rt nasal nostril & Lymphoma & 20 & 1999 \\
\hline Watanabe and Suzukil & $88 / F$ & Japan & Nasal mass & Lt nasal vestibule & ND & 20 & 1999 \\
\hline Tardío and Martín-Fragueiro ${ }^{12)}$ & $45 / M$ & Spain & $\begin{array}{l}\text { Nasal obstruction, } \\
\text { Recurrent epistaxis }\end{array}$ & Rt lateral wall & DM & 15 & 2002 \\
\hline Banerjee et al. ${ }^{11)}$ & $34 / F$ & UK & $\begin{array}{l}\text { Nasal obstruction, } \\
\text { Recurrent epistaxis }\end{array}$ & Lt nasal cavity & None & 20 & 2001 \\
\hline Erkiliç et al. ${ }^{13)}$ & $52 / M$ & Turkey & Nasal obstruction & Lt nasal cavity & None & 35 & 2005 \\
\hline $\mathrm{Go}^{3)}$ & $44 / M$ & Korea & Nasal mass & Rt posterior choana & ND & 13 & 2005 \\
\hline Moreira et al. ${ }^{14)}$ & $54 / M$ & Brazil & Recurrent epistaxis & L† inferior meatus & None & 20 & 2011 \\
\hline Ahn et al. ${ }^{4)}$ & $56 / M$ & Korea & $\begin{array}{l}\text { Nasal obstruction, } \\
\text { Foreign body sense }\end{array}$ & Rt posterior choana & DM & 25 & 2013 \\
\hline Iwata et al. ${ }^{6}$ & $60 / M$ & US & Recurrent epistaxis & Rt anterior nasal cavity & none & 16 & 2013 \\
\hline Park et al. ${ }^{5)}$ & $55 / M$ & Korea & Recurrent epistaxis & Rt anterior nasal cavity & ND & 11 & 2013 \\
\hline Aleem et al. ${ }^{15)}$ & $50 / F$ & India & Nasal obstruction & Lt posterior nasal cavity & ND & 13 & 2017 \\
\hline Aleem et al. ${ }^{15)}$ & $60 / M$ & India & Recurrent epistaxis & Lt nasal cavity roof & ND & 8 & 2017 \\
\hline Present case & $29 / M$ & Korea & Nasal obstruction & Lt posterior nasal cavity & $A R$ & 15 & 2017 \\
\hline
\end{tabular}

US: United State, UK: United Kingdom, DM: diabetes mellitus, HTN: hypertension, AR: allergic rhinitis, ND: no data

호발하는 것과 대조적으로 비강 내 발생한 혈관근육지방종 의 경우 남성 12 명, 여성 4 명으로 $3: 1$ 의 비율로 남성에서 호 발하였다. 중동과 아시아 나라의 남성에서 호발하는 경향을 보여 유전적 영향이 있을 것으로 추정이 되나, 현재까지 비강 내 발생한 혈관근육지방종의 분자적, 세포유전학적 변화에 대한 문헌은 보고된 바는 없다. ${ }^{15)}$

주된 증상은 비폐색과 잦은 비출혈이 각각 7예로, 3예의 환자에서는 비폐색과 비출혈을 동시에 호소하였다. 우측 비 강에서 발생한 경우가 8예, 좌측 비강에서 발생한 경우가 8 예로 우세한 방향은 없었다. 종물의 크기는 $8 \mathrm{~mm}$ 에서 40 $\mathrm{mm}$ 였으며, 평균 크기는 $19 \mathrm{~mm}$ 로 신장과 간에서 발생하는 혈관근육지방종에 비해 작은 크기였다. 지금까지 보고된 증 례의 환자에서 결절경화증의 병력이 있는 환자의 예는 없었 고, 수술 전 부비동 전산화단층촬영과 수술소견에서 골파괴 및 침범소견이나 절제 후 재발소견이 보고된 증례는 없었다.

본례의 경우 철저한 신체 검사가 없었다면 코막힘의 원인 이 단순한 알레르기 비염으로 오인될 수 있었던 사례로 젊은 남자 환자에서 비강 내 혈관근육지방종이 발생할 수 있음을 보고하고자 한다.

\section{Author Contribution}

Conceptualization: Jung Soo Kim. Data curation: Min Chul Ko, Jung Soo Kim. Formal analysis: Min Chul Ko, Sung Jae Heo, Jung Soo Kim. Investigation: Min Chul Ko. Methodology: Min Chul Ko, Sung Jae Heo, Jung Soo Kim. Project administration: Sung Jae Heo,
Jung Soo Kim. Resources: Min Chul Ko, Jung Soo Kim. Software: Min Chul Ko, Sung Jae Heo. Supervision: Sung Jae Heo, Jung Soo Kim. Validation: Min Chul Ko, Sung Jae Heo, Jung Soo Kim. Visualization: Min Chul Ko, Sung Jae Heo, Jung Soo Kim. Writingoriginal draft: Min Chul Ko. Writing - review \& editing: Min Chul Ko, Sung Jae Heo, Jung Soo Kim.

\section{ORCID}

Jung Soo Kim

$$
\text { https://orcid.org/0000-0002-0899-3794 }
$$

\section{REFERENCES}

1) Watanabe K, Suzuki T. Mucocutaneous angiomyolipoma. A report of 2 cases arising in the nasal cavity. Arch Pathol Lab Med 1999; 123(9):789-92.

2) Dawlatly EE, Anim JT, el-Hassan AY. Angiomyolipoma of the nasal cavity. J Laryngol Otol 1988;102(12):1156-8.

3) Go JH. Angiomyolipoma of the nasal cavity. Korean J Pathol 2005; 39(4):284-6.

4) Ahn SH, Lee YJ, Kim CH, Chang JH. Angiomyolipoma of the nasal cavity resected with preoperative angio-embolization. Korean J Otorhinolaryngol-Head Neck Surg 2013;56:528-31.

5) Park WK, Kang MS, Park SK. A case of angiomyolipoma of the nasal cavity. Korean J Otorhinolaryngol-Head Neck Surg 2013; 56(6):383-5.

6) Iwata AJ, Friedmann DR, Kaplan J, Wang BY, Lebowitz RA. A man with recurrent right-sided epistaxis. Angiomyolipoma (AML) of the nasal cavity. JAMA Otolaryngol Head Neck Surg 2013;139 (10):1067-8

7) Ashfaq R, Weinberg AG, Albores-Saavedra J. Renal angiomyolipomas and HMB-45 reactivity. Cancer 1993;71(10):3091-7.

8) Park JJ, Choi SM, Yoon SW, Kim EK. A case of angiomyolipoma originated in larynx. JAMA Otolaryngol Head Neck Surg 2007;50 (3):278-80. 
9) Güezmes A, Mazorra F, García-Mantilla F, Eizaguirre MJ, Ondiviela R. [Nasal angiomyolipoma]. Acta Otorrinolaringol Esp 1990;41(5): 341-2.

10) Gatalica Z, Lowry LD, Petersen RO. Angiomyolipoma of the nasal cavity: Case report and review of the literature. Head Neck 1994;16 (3):278-81.

11) Banerjee SS, Eyden B, Trenholm PW, Sheikh MY, Wakamatsu K, Ancans J, et al. Monotypic angiomyolipoma of the nasal cavity: A heretofore undescribed occurrence. Int J Surg Pathol 2001;9(4):30915.

12) Tardío JC, Martín-Fragueiro LM. Angiomyolipoma of the nasal cavity. Histopathology 2002;41(2):174-5.
13) Erkiliç S, Koçer NE, Mumbuç S, Kanlikama M. Nasal angiomyolipoma. Acta Otolaryngol 2005;125(4):446-8.

14) Moreira MD, Lessa MM, Lima CM, Lessa HA, Fonseca LE Júnior. Angiomyolipoma of the nasal cavity. Braz J Otorhinolaryngol 2011;77(2):269.

15) Aleem MA, Fatima A, Kumudachalam P, Priyadarshini R. Nasal angiomyolipoma: Report of two cases of an extremely rare entity. Indian J Pathol Microbiol 2017;60(3):393-5.

16) van Baal JG, Smits NJ, Keeman JN, Lindhout D, Verhoef $S$. The evolution of renal angiomyolipomas in patients with tuberous sclerosis. J Urol 1994;152(1):35-8. 